\title{
The Threepenny Opera: A Director's Take on an Unconventional Musical
}

\author{
By Sidney Homan*
}

\begin{abstract}
After placing "The Threepenny Opera" within the context of the evolution of the musical comedy from light entertainment to serving as a mirror for the issues of society, the director recounts his own experience staging the Brecht/Weill musical in terms of its metadramatic statement, the paradox of its self-effacing nature coupled with serious political issues, the role of its audience at once engaged and disengaged, the function of its unconventional score, and the work as reflecting the larger world offstage. His production draws and comments on stagings of this unconventional musical over the past eighty years.
\end{abstract}

\section{Introduction}

During a trip to New York in 1956, when my impoverished high-school buddy and I saw the marquee of the Theatre De Lys advertising that matinee tickets for The Threepenny Opera were half price, we jumped at the chance. The cabaret orchestra onstage, the underworld setting, the anti-hero Macheath, the bold lyrics, the trenchant dialogue, the feel of this "European" musical, not an opera, as we soon discovered, but a parody of Handel and Verdi, and Franz Lehar and Victor Herbert as well-for us, all this was a revelation. When the Messenger came down the aisle in the final scene, converting what looked like an inevitable tragedy, Macheath's execution, to a happy ending, we were delighted, only to be pulled back to reality by Mrs. Peachum's reminder that in real life there are no last-minute messengers, that things do not work out this way. The New York audience was also taken in by that ending, alternately shocked, confused, embarrassed, pleased, and offended. Brecht' s "alienation effect" had worked perfectly.

Before hitchhiking home to Philadelphia, we decided to stop at a nearby Village restaurant. The place was crowded, the only available table a round eight-seater. We ordered espresso, and if berets had been available would have worn them, immersed as we were in the pose of Bohemians straight from this artsy experience at the Theatre De Lys. To our surprise, in came Miss Lenya and some of the Threepenny cast, on a break before the evening show. They had to sit at our table! Lotte Lenya, Jenny, on my right! For the next hour, with the actors wolfing down food, we had a wonderful conversation. Doubtless, they were amused by these two gushing young boys so full of questions. What was Bertolt Brecht like? Kurt Weill? Staging the

*Professor of English, University of Florida, USA. 
show in Germany of the 1930s? Here in New York? They were happy to answer our questions but finally had to leave to make call. My grandmother had told me sophisticated European ladies liked to have their hands kissed, so I stood and put my lips to Miss Lenya's, feeling gallant though probably looking very awkward. She thanked me, laughing in an understanding way, then, throwing a kiss to us, left with the actors. Now, almost fifty years later, I would have a chance to direct Threepenny at the Acrosstown Repertory Theatre in Gainesville, Florida.

\section{A Context for The Threepenny Opera}

Before staging the Brecht/Weill piece, I needed to understand it in the context of the musical comedy, both the unconventional and the conventional. ${ }^{1}$ The latter usually applies to a work in two acts, the first longer than the second, with most of the major songs introduced in the first act. With less time in a musical to devote to the drama than in a straight play, the music assumes a greater role. The old adage usually applies to the genre: when the emotion becomes too strong for speech you sing, and when too strong for song, you dance. The term "musical comedy" itself was first used in The Black Domino/Between You, Me, and the Post of the 1860s. Aware that the more sophisticated operettas of Gilbert and Sullivan, like H.M.S Pinafore (1878), were not for all tastes, wanting musicals for a general, "public" audience, impresarios like George Edwardes staged In Town (1892) and Gaiety Girl (1893), where the "breezy music" was complemented with "snappy, romantic banter, and stylist spectacle." 2 Songs usually grew out of the dialogue, reflecting the ongoing events of the story, but the relation between the music and the script was often thin, at best complementary.

Showboat (1927) is often cited as the American musical comedy that turned the tide, with its trenchant commentary on the old South and-radical for the

1. Chuck Crisafulli, "Unconventional Musical Sing a Different Tune," Entertainment News, last modified November, 16, 2007, accessed January 12, 2017, goo.gl/FKSIYl; The Most Influential Broadway Shows of All Time, accessed January 12, 2017, goo.gl/q5Eqju.

2. For information on what is conventional in the Broadway musical and a detailed history of the genre's evolution, see David Rooney, "Review: Broadway: The American Musical," Variety, last modified October 19, 2004, accessed February 10, 2017, goo.gl/zK8Csb. Also, the following are invaluable for the history of the genre: Don B. Wilmeth, and Tice L. Miller, ed., Cambridge Guide to American Theatre (Cambridge: Cambridge University Press, 1996), [2nd ed.]; Gerald Bordman, American Musical Theatre: A Chronicle (New York: Oxford University Press, 1978); David Ewen, The Story of American Musical Theater (Philadelphia: Chilton, 1961), [1st ed.]; Larry Stempel, Showtime: A History of the Broadway Musical Theater (New York: W.W. Norton, 2010). 
day - an interracial romance. Indeed, in his masterful documentary, Broadway: The American Musical, Michael Kantor divides its history as "before" and "after" the Jerome Kern musical. ${ }^{3}$ A hybrid opera and musical, Gershwin's Porgy and Bess also challenged what was conventional; it premiered in 1935, just a few years after Brecht revised The Threepenny Opera. Even Oklahoma, once seen as "conventional," started to break the mold. Instead of beginning with the generic chorus, often an extension of the overture, the Rogers and Hammerstein work opens with a single woman onstage, churning butter, and we hear Curly singing "Oh, What a Beautiful Morning" from offstage.

Perhaps not always as focused or as profound as straight plays, still, musical comedies began to take up important themes, however much these themes were, in the view of some critics, diluted by the need to include hit songs and dialogue that at best is a partner with the music. World War II led to Cabaret (1966). In Evita (1978), a detailed and serious biography was the source. Sweeny Todd (2007) is based on the urban legend of the demon barber who kills his victims by slitting their throats, and West Side Story (1961) treats the conflict between a white and Puerto Ricans gang-Jerome Robbins had originally proposed that the clash be between an Irish Catholic and a Jewish family living on the lower east side of Manhattan. Race is an issue in Finian's Rainbow (1947), South Pacific (1949), and The King and I (1951), and homosexuality in Hair (1967) and La Cage aux Folles (1983). There are serious themes in Sondheim's Company (1971), Follies (1972), and A Little Night Music (1973). The steel strike was the issue in The Cradle Will Rock (1937). The rock-musical Rent reworks Puccini La Bohème and takes up the plight of impoverished young artists in New York City.

Not driven by the business model of a popular Broadway musical like The Lion King or Mama Mia, nor the concomitant need to reach a general audience, it was the off-Broadway musical-predictably-that moved toward the unconventional.

Off-Broadway tackled controversial subjects that often employed frank prominent on-stage nudity in a way quite unthinkable in the typical Broadway musical. It all started when Hair in 1968 moved from off-Broadway to Broadway. Then there was nudity in Oh! Calcutta! (1969) and its imitators, Stag Movie and Let My People Come, and more recently Naked Boys Singing (1998), Falsettos (1992), and Spring Awakening (2006). In a series of rulings (Roth v. US, 1957; Jacobellis v. Ohio, 1964; Miller v. California, 1973) the Supreme Court "made the term 'obscenity' increasingly impossible to define," as Elizabeth Wollman points out. ${ }^{4}$

Some of the current off-Broadway offerings underscore this change in subject matter and style: a wanted woman trying for a new life in the West

3. Rooney, "Review: Broadway: The American Musical."

4. Elizabeth Wollman, commentary reprinted as Nudie Musicals in 1970s New York City, last modified April 6, 2014, accessed January 15, 2017, goo.gl/JBDiWP; New York Theater Guide, accessed January 15, 2017, goo.gl/6CvPxU. 
(Bella: An American Tale); a musical drama of the life of a Hollywood star (Cagney); the myth of The Iliad and The Odyssey reshaped into an all-American fable (The Golden Apple); the life of Joan of Arc in a rock-musical concert, with music by David Byrne, lead singer of the Talking Heads (Joan of Arc: Into the Fire); a satire on everything from the Tea Party to Arizona immigration laws, Don't Ask Don't Tell to Lindsay Lohan (Newsical The Musical); a musical takeoff on Shakespeare's Othello where a married couple, fed up with the city's noise and pollution, as well as high rents, finds a home in "the final frontier" (Othello the Remix); Commodore Matthew Perry's 1853 sailing to Japan to force trade relations with that country (Pacific Overtures); women cleaning out a grandmother's attic and finding a treasure of old memories, the history of black women from the 1930s trials, to the Girl Groups of the 60s, to empowerment of the 90 s (Sistas). ${ }^{4}$

And then there is Hamilton (2015), which in the words of Mark Binelli in The Rolling Stones is "a reckoning with our country's creation myth," where there is an "almost indescribable power in seeing the Founders, in an otherwise historically rigorous production, portrayed by a young, multiracial cast."5 Rebecca Mead comments on the musical's reference to the Presidency of the nation's first African American, presenting "the birth of the nation in an unfamiliar but necessary light: not solely as the work of élite white men but as the foundational story of all Americans."6 Much of the score is rap music. Clearly the musical has moved far from the stylish dance numbers of the Ziegfeld Follies or even the marvelous songs hitched to the forgettable plots of Lady Be Good (1924) or No, No, Nanette (1925).

$$
* * *
$$

Opening on August 31, 1928 at Berlin's Theater am Schiffbauerdamm, The Threepenny Opera went beyond what most musical comedies had been, even as it anticipated the changes the would occur-from the subject matter, to the characterization, the part played by the music, an innovation in form that in turn affected staging, and the role of the audience. Born in the fading days of the Weimer Republic, the show was revised by Brecht in 1931 as that rough beast Hitler was slouching toward Berlin. The opening night audience sat on their hands for most of the first act, until Macheath and Tiger Brown's duet "The Army Song." Despite the critics, audiences loved the show and it became a great success. Steve Giles points out that in the 1931 version, which

5. Mark Binelli, "Hamilton Creator Lin-Manuel Miranda: The Rolling Stone Interview," Rolling Stone Magazine, June 1 (2016), accessed January 12, 2017, goo.gl/PfsOui. And see Spamilton playing off-Broadway, a side-splitting musical "that roasts, eviscerates and celebrates Lin-Manuel Miranda's hit Broadway musical Hamilton, New York Theatre Guide, goo.gl/6CvPxU.

6. Rebecca Mead, "All about Hamilton," The New Yorker, February 9, 2015, accessed January 12, 2017, goo.gl/pdStfT. 
provides the basic text for modern-day productions, Brecht brought the work more in line with his principles of Epic Theatre and Marxism. And the music! All embracing, the score includes parodies of Handel, sardonic ballads that reflect the growing despair of pre- and post-Hitler Germany, the catchy ragtime tunes of music halls, opera-like arias that, no less than the script, dig into the character's deepest needs and anxieties, and-given Weill's modernist style as a composer-a score that varies between tonal and atonal, symmetrical and asymmetrical rhythms. ${ }^{7}$ Because of my experience in seeing the 1950s New York production, I was thrilled when I was asked to direct The Threepenny Opera. ${ }^{8}$

\section{Involving the Audience in Its Self-Conscious Theatre}

At every point, The Threepenny Opera calls attention to itself, refusing to allow the audience to abandon themselves to what Brecht would dismiss as the "theatre of illusion." 9 The audience's presence becomes integral; rather than remaining comfortable voyeurs in the dark, they are appealed to by the actors, are present with them, contemplating what is happening and thereby making a contribution to the performance. For Brecht, the actor is at once "in character" and "outside" the character, aware of the political, historical, and economic forces driving him or her. ${ }^{10}$ Threepenny thereby breaches that illusory fourth wall, reaching out "to people sitting on either side of you," as

7. See Steve Giles detailed examination of the history of The Threepenny Opera, Brecht's revision of the original work, and an analysis of its politic and the psychological make-up of its characters, "The Threepenny Opera," accessed January 12, 2017, goo.gl/wNW0i4.

8. Bertolt Brecht, The Threepenny Opera - English book by Desmond Vesey, English lyrics by Eric Bentley, A foreword by Lotte Lenya, ed. Eric Bentley (New York: Grove Press, 1964). And see David Farneth, "'Look, There Goes Mack the Knife'," "Program Notes" from the original Decca Record Album of The Threepenny Opera. For commentary on the Blitzstein adaptation, see: Fred Flaxman, "Transcript for the Piece Audio Version of Compact Discoveries 158: The Threepenny Opera", goo.gl/QOmTXk. Production of The Threepenny Opera at the Acrosstown Repertory Theatre, Gainesville, Florida, May-June, 2004.

9. Werner Hecht, "The Development of Brecht's Theory of Epic Theater: 1918-1933," Tulane Drama Review 6 (1961).

10. For Brecht's dramatic theory see: Ronald Gray, Brecht the Dramatist (Cambridge: Cambridge University Press, 1978); Jan R. Needle and Peter Thompson, Brecht (Chicago: University of Chicago Press, 1981); Walter H. Sokel, "Brecht's Concept of Character," Comparative Drama 3 (1971); W. A. J. Steer, "Brecht's Epic Theatre: Theory and Practice," Modern Language Review 63 (1968): 637. 
Stephanie Sandberg, the director of the Odyssey Theatre Ensemble's production in Los Angeles, has said. ${ }^{11}$

It is also designed to remind us it is just a play - not real, fraudulent. We heightened this paradox in our production at the Acrosstown. In the wedding scene, for example, the presents were all real, but my properties designer had made patently fake champagne glasses, two-dimensional cardboard shapes with the terrible pun "Brute" on the cardboard champagne bottle. To underscore this theatrical illusion, we had the actors step out of their roles to become stagehands and then turn the revolving set from a realistic beggars establishment to an equally realistic stable.

Brecht continually underscores the audience's presence. At the end of "Jenny's Pirate Song," that dark intrusion on the otherwise comic wedding scene that one critic saw as "loaded with Freudian cannon,"12 the four crooks, Macheath's associates, stand upstage and utter a reviewer's clichés about the performance we all have just seen. For a moment these low-life characters become caricatures of theatre critics: "Quite a little voice," "Comical," "And how she lays it on, she does" (16). This is only the most obvious of those many selfconscious, metadramatic moments where The Threepenny Opera reflects on itself, balancing its social and political commentary with theatrical presence. And that presence, by definition, involves the audience: the basis of our experience is the theatre itself, what is presently happening onstage. A director friend once said if Godot does not come for the two characters onstage, he does not come for those in the house. The audience is part of the work's metaphoric basis in Beckett no less than in the Brecht/Weill Threepenny.

The Acrosstown is a small house, under 100 seats in semi-round, and so the audience is close to the action. As a director, I felt the need to remind them of their co-equal role. We made no effort to disguise the fact that the actor playing Matt doubled as the Reverend Kimball, and even did away with an off-stage costume change, having him leap like Superman into the telephone booth downstage left and there, before everyone, metamorphose from crook to minister. While Kimball took his position as church official seriously, the audience was under no illusion that this was anything more than a hasty stage impersonation.

11. Sharon Perlmutter, "Regional Reviews: Los Angeles - The Threepenny Opera," Talkin' Broadway, accessed December 15, 2017, goo.gl/n18ZBb.

12. John Fuegi, Brecht and Company: Sex, Politics, and the Making of the Modern Drama (New York: Grove Press, 1994), speaks of Jenny's ship as "loaded with Freudian cannon," her dream that of a world where women will determine when men live or die. $\mathrm{He}$ contrasts the women who dream "of either equality or, failing that, of seizing power" with "man's dream of infinite prolongation of the days of shooting other races, of ... rape and murder, of a world of buying and selling the bodies of women" (206). 


\section{Acknowledging the Work's Self-Effacing Nature}

On the Street Singer's announcement that the audience is in for a dubious performance, an opera so cheap that "even a beggar could afford it" (1), the crowd-the entire cast except Macheath-poured onstage, mocking one of those artificial scenes of "street life" from Busby Berkeley Hollywood musicals of the 1940s, and interacting with the audience on the front row. Actors were desperately pretending to be real people, the small stage proclaiming itself a fake city street concocted by the designer. (In David Fuller's 2003 Threepenny in New York the actors sometimes exited into the streets of East Village, the play "spilling into the audience and out the fire exit."13) With exaggerated gestures and dialogue short of articulated speech, prostitutes plied their trade. Elegant people, indifferent to the beggars and bums, sauntered from one end of the stage to the other, accompanied by stereotyped vignettes of real life-assignations, thefts, trysts.

Directors have taken many options for opening the play. The production at the Jean Cocteau Repertory Theatre revealed a graphic Victorian underground behind a patently cheap proscenium curtain; in the 2005 Odyssey Theatre Ensemble staging in Los Angeles, actors in whiteface escorted the audience to their seats. An image of Queen Victoria with swastika earrings and a mustache was projected over the audience at Peter Hunt's Williamstown Theatre production in 2003, while the Glasgow Citizens Company's Threepenny Opera opened in a pink and blue saloon soon to be invaded by the beggars. One reviewer commented that the audience looked at the poor through the eyes of the welloff, while beggars lived out the fantasy of "exterminating the rich." At the start of the Avon Theatre's production, "a frankly fake person" burst in through a side street, tussled with the ushers, and then muscled "his way onto the stage to sing 'Mack the Knife' before getting the boot."14

Like Puck's epilogue with his dismissive comments about the stage's illusion ("If we shadows have offended ... . Think but this and all is mended ... that this weak and idle theme [is] no more yielding than a dream"), our Threepenny consistently dismissed itself as a mere illusion, the way Shakespeare's

13. John T. Gilber notes that "even though [The Threepenny Opera] opened up a new possibility for the musical stage, it represented for [Brecht] the most primitive form of opera" (Michael John T. Gilbert, Bertolt Brecht's Striving for Reason, Even in Music: A Critical Assessment (New York: Peter Lang, 1988), 71).

14. Neil Genzlinger, "Those Beggars and Thieves Are on the Loose," The New York Times, last modified September 10, 2003, goo.gl/h3dYXf. And see Matthew Murray, "Off Broadway Reviews - 6 Women With Brain Death," Talkin' Broadway, accessed August 6, 2011, goo.gl/xbA1qE; Perlmutter, "Regional Reviews: Los Angeles;" David Z. Mairowitz, The Threepenny Opera by Bertold Brecht/Kurt Weill - Plays and Players, accessed August 6, 2011, goo.gl/eQRbvS. 
self-effacing titles do: Much Ado about Nothing; As You Like It; Twelfth Night, or What You Will.

\section{Working Against Such Self-Effacement}

This dismissive, "light" attitude, however, coexists with the work's dead seriousness. Born from John Gay's eighteenth-century The Beggar's Opera, from an era of otherwise frivolous theatre, Threepenny is a cry of protest, speaking to current conditions in London, having evolved from Germany in the fading days of the Weimar Republic to Hitler's "Thousand Year Reich" of the 1930s, to-in our production-the back streets of New York, that seedy underbelly of this city otherwise marked by culture and wealth and sophistication. ${ }^{15}$ Among others, The New Repertory Theatre and the Williamstown Theatre Festival set the play in 1930s Berlin, and Blanka Zizka staged hers in the American 1920s of Calvin Coolidge, with an African-American in the role of Macheath. ${ }^{16}$

At times this seriousness was inseparable from, indeed was heightened by the production's self-conscious theatrics. When Mrs. Peachum delivered her "Dependency Song," the four prostitutes she had summoned sat downstage in a semi-circle around her, creating an extension of the front row audience only a few feet behind them. Seconds before she was about to call for a chair to sit on as she sang, the stage manager rushed out with one. This profound song, making a graphic connection between aggressive male demands and sexual dependency, was no less a set piece, something one might hear in a nightclub, and so the lights focused entirely on Mrs. Peachum. ${ }^{17}$ Later, when she reprised that song, she moved even further into the real audience, positioning herself between the two halves of the house, leaning seductively against a railing separating audience-left from the downstage entrance, this time singing not to the prostitutes but directly to spectators caught in the light spill. The reviewer for a 2004 Boston production found it "surprisingly effective" when director Rick Lombardo had Mrs. Peachum "retreat to the side and

15. John Willett notes that John Gay's target is the aristocracy who behave like lowlife criminals, whereas Brecht's is the underworld who behave like aristocracy (John Willett, The Theater of Bertolt Brecht (New York: New Directions, 1968), 82).

16. Ed Siegel, "Threepenny Production Is on the Money," The Boston Globe, last modified January 13, 2004, accessed August 6, 2011, goo.gl/BVjuoW; Ben Brantley, "The Fine Art of Slumming It," The New York Times, last modified July 4, 2003, accessed August 6, 2011, goo.gl/j9PZrG; Steven Henderson, "The Persistence of Brecht," American Theatre 15, no. 5 (May/June, 1998).

17. Willett points out that in the "songs must always remain distinct from the dialogue" (Willett, The Theater of Bertolt Brecht, 131-132). 
watch the plot unfold" after delivering her song. ${ }^{18}$ Metadrama thereby highlighted the work's deeper subtext, theatrical illusion being the prime connection between actor and audience.

Even during small moments this theatrical self-consciousness is enveloped by an atmosphere that is more real. ${ }^{19}$ As Macheath is about to be hanged, he compliments Polly with, "That's a beautiful dress you're wearing," and her "Like it?" (57) is that of a young girl on her first prom rather than a soon-to-be widow dressed up for her husband's execution. A snippet of the ordinary, mundane, domestic, and gloriously irrelevant to the serious occasion flits across the stage and then is itself subsumed by Macheath's suddenly breaking into the morose song, "Death Message."

This metadramatic dimension battles the real world, both that depicted onstage and existing outside the theatre. Claire Allfree in a review of the recent National Theatre production speaks of that onstage world's "hollow, desolate heart," revealing "a cheerless sham of a place within which London's destitute really are mad and bad." 20

At times the stage illusion assaults the reality of the spectators in the house. When Peachum in the final scene stepped offstage, the house lights came on in good Brechtian fashion as he announced to the "Dear honored public" that the scene they anticipate, Macheath's death, will be averted, that "we [playwrights and actors] have devised a rather pleasantly different solution" (58). Once said, he resumed his position onstage, and the play continued as if the other characters were totally unaware of the break. Peachum's four lines had announced a plot change that did not exist in their "real" world onstage.

Yet even this last vestige of onstage realism is dispelled with the arrival of the Messenger, and here I was clearly influenced by that original production at the Theatre De Lys. Riding a patently unreal horse-a plastic horse head stuck on a broomstick - the Messenger emerged from between the two audience sections to announce Macheath's "reprieve."

18. Siegel, "Threepenny Production Is on the Money."

19. Fuegi reminds us that during the 1928 production Berlin itself was a "vast array of the poor, homeless, crippled, and chronically undernourished" (Fuegi, Brecht and Company:, 205).

20. Clare Allfree, "The Threepenny Opera, National Theatre, review: 'It chills more than it thrills'," The Telegraph, last modified May 27, 2016, accessed February 10, 2017, goo.gl/G75DGm. 


\section{Balancing Identification and Distance for the Audience}

Threepenny's penetrating look into the middle class is parodied by the criminal elements who ape the former's "family values" as well as their business ethics (or lack thereof). The crooks share our concerns, no matter how perverse their lives or nefarious their trades. In film, this is the Mafia boss who one moment is brutal, the next a loving grandfather at a child's birthday party.

The first scene in the brothel might just as well be housewives chatting over coffee about relatives, dresses, letters from loved ones, and the economy"earning power isn't what it used to be" (33), as one remarks without naming the profession. Whatever the girls do at night, here in the daytime they resemble "respectable" women.

Although held in a stable, the gifts and furnishings stolen, the wedding (1.2) plays off of similar ceremonies in polite society. Men of good taste for the occasion, for the bridal feast the criminals steal food from the finest shops in London and furnishings from wealthy homes in fashionable sections of town. Macheath's praise of his bride is the generic stilted speech prerequisite for such occasions. We emphasized this schism between theatre and reality with a revolving set, so that the side establishing Peachum's beggars emporium turned to reveal the stable's back wall; respectability and criminality were simply two sides of the same coin.

To bring the production even closer to our audience we changed the location from London in the 1890s to present-day New York City. The Queen became "Her Honor the Mayor," the Tower, the Brooklyn City Jail. Macheath tried to flee not to Manchester but to Newark, New Jersey. Brecht, to be sure, likes historical settings so that the audience can contemplate a period other than their own, before making applications to the present, ${ }^{21}$ but I felt I needed to make this work from the 1920s more accessible to our present-day audience. Michael Feingold's translation for the American Conservatory Theatre set the play in present-day San Francisco, with references to Union Street, Howard Street, and the city's financial district. Bartlett Sher, directing a North Carolina Threepenny, argues that "the only way to do Brecht in America at this moment is to fling yourself right into the decadence," whether it be New York or San Francisco, or any other city.22

While their costumes were shabby, at a distance the criminals could pass for young office workers; the women's outfits were a bit tawdry but nothing

21. However, Martin Esslin insists that the action is not to take place in the "total present but in a strictly define historical past" (Martin Esslin, Bertolt Brecht - Issue 42 (New York: Columbia University Press, 1969), 13).

22. Steven Winn, "Bright, Polished "Threepenny"/"Opera's" four principal women turn in brilliant performances at ACT," San Francisco Gate, last modified September 10, 1999, accessed August 6, 2011, goo.gl/mfrf2j; Henderson, "The Persistence of Brecht." 
out of the ordinary. The Peachums, along with Polly, were the model of middle-class dress as well as values.

We played these (almost) domestic scenes in a distinct style, the delivery quick, comic, the continuous chatter and one-liners masking the paper-thin morality of the people involved. Polly and Lucy battle over Macheath, each on one side of the jail cell, their mutual husband hemmed in by the closeness and cattiness of the bickering women. Macheath always won the sympathy of the audience. Every once in a while he would look into the house, hoping to spot an understanding face, at times apologizing for the women's behavior, at other times wishing he were rid of them both.

\section{Respecting the Unconventional Songs}

Especially with the songs, we did not want the audience to get too comfortable, and so we stressed, instead, the tension between the music and lyrics. The sweet, seductive nature of the songs cannot obfuscate the words exposing the reality of Brecht's world. The opening number, "Mack the Knife," made popular by a score of singers from the 1950s to gangsta rap today, is a finger-snapping, toe-taping piece, yet it houses lyrics of the grotesque: snap-shots of bodies oozing down into the river, killings on the streets, the sleaze and horrors of life on the city's back streets. Our audiences invariably sang along or clapped their hands in rhythm, while onstage, as graphically as we could manage, we displayed the unsavory tableaux suggested by the lyrics.

The Peachums' "Instead Of" duet is alternately romantic and cynical, first celebrating love with "You feel my heart beating" and then exposing its tawdry side as love turns to hate, promise to failure. The melody is catchy, but we made sure the audience paid equal attention to the lyrics by having four loving couples cross from upstage to downstage in the song's first half, then, when things turn sour, cross back upstage, this time quarreling, glaring at each other, with one of the women going so far as to slap her mate. In the generic musical the songs can often be detached from the script; the Threepenny songs are inseparable from the action and dialogue. In one production the actors "deliver[ed] large chunks of songs straight at the audience, standing stock-still."23

If we felt the need to underscore the content in other songs, we had a very different problem with "Solomon's Song." I found the lyrics a bit preachy, these several stories of historical figures who come to unfortunate ends. While my younger actors, who at first found Weill's music "odd" and "not our style," had grown to love the score; still, everyone was uneasy with "Solomon's Song."

23. Neil Genzlinger, "Those Beggars and Thieves Are on the Loose," The New York Times, last modified September 10, 2003, goo.gl/h3dYXf. 
One actor then suggested we "jazz up" the number and, as if by instinct, cast members began clicking their fingers, doubling the speed, putting the emphasis in the first line, for example, on the "mem" and "sol" in "Remember wise old Solomon." The Musical Director improvised a jazz score, a mingling of Dave Brubeck and Charlie Mingus, and soon my Jenny was belting out a cool reworking of Weill's melody in café-singer style. Another actor moved an upstage-right lamppost to center stage, and Jenny now curled around it, beckoning customers with her song and her body. Then we added a "living tableaux" for two of the historical figures. Solomon, played by our youngest cast member, a teenage boy, had four prostitutes leer and hover over him as he illustrated each item in Jenny's history with a gesture or expression, much like those exaggerated mannerisms of silent film actors. For Caesar, an older actor stood amidst the conspirators, who passed invisible swords through his body. ${ }^{24}$ Writhing in pain, he backed upstage left, tipping his hat like some boulevard gallant on Jenny's "Guess not."

The nightclub scene would take on an added dimension. One night, as Jenny moved toward the lamppost and the characters for the tableaux got into place, our Musical Director, impersonating Ray Charles, tapping his cane as he moved toward the piano, approached our regular accompanist, a classically trained pianist quite comfortable with Weill's music but insecure playing improvised jazz. He pushed her off the bench and took her place. She pouted and raced offstage.

Then, suddenly it was over; the mood darkened as the lamppost was moved back into its normal place and the imitation Ray Charles left the stageunwillingly, it should be added. General lighting came on, and we were back in the story. The Street Singer appeared to announce that Macheath was "about to be hanged" (54).

The next three songs from Macheath's jail cell presented even more of a challenge than "Solomon's Song." The music here is harsh, disquieting, the beat staccato, without a clearly defined melody, more like non-melodic punctuation for the lyrics. Yet the songs take Macheath's character to a new level. Up to this point he has been the charming con man, comically self-centered, capable of only the most superficial relationships, not liberated when it comes to women, at best a good but imperious companion with men. Brecht speaks of a fatalism about Macheath, an indifference to life, what Samuel Beckett brands as apathy in his own anti-hero Belacqua Shua of More Pricks Than Kicks, patterned on those sad figures from the circle of the indifferent in Dante's Inferno. ${ }^{25}$

24. The irony is this same actor had played Caesar in a production of Julius Caesar I directed at the Acrosstown Repertory Theatre, March/April, 2002.

25. Sidney Homan, Beckett's Theater's: Interpretations for Performance (Lewisburg, PA: Bucknell University Press, 1984), 174-175. 
Macheath's first "Call from the Grave" (55) is a simple plea for help, where he uses various persuasions: throwing himself on the mercy of the audience, hoping they hear "his dying call," flattering them with the word "friends," asking rhetorically if they have any sympathy for his plight while reminding them that there is still time to save him. We brought Macheath out of the cell for this first song, as if the doors had opened by magic, or as if the audience had been allowed into the cell and then into his mind and heart. Once the song was over, Macheath went mechanically back into the cell, closing the door himself, and then, reverting to his earlier character, negotiating with his gang on the payment for his release, before ordering asparagus for his last meal.

The second "call" is more involved (56). At first, he begs the audience to learn from his "sorry plight," to resist his mistake in pursuing "dirty cash." But the warning quickly changes to an appeal to the audience to forget their wretched lives and come to his aid by storming the royal court to plead his "cause." He ends with a cry, "Don't let him rot eternally in hell." The moment the song is over Macheath again reverts to his old self, humiliating Tiger Brown with "there are others I'd prefer to pay me the last hours" (57). In this one song, we are privy to a deeper region of this anti-hero's personality than we have known before - a taste for cruelty, a cold indifference to others, a colossal ego, a bitterness and cynicism that was there in potential from his opening scene but now emerge fully.

When the cast rushes onstage to see the execution, once Macheath has, in effect, an audience, he adopts a more public voice for his final song, "Death Message" (58). While he still asks them to intercede with God to pardon him, this time he makes himself a symbol for all the downtrodden, calling for mercy, for withholding judgment on the less fortunate. He blames his criminality on history, economics, the environment. While this might be only a defensive measure, a sign of Macheath's failure to take responsibility, there may also be some truth in the assertion. Wrong though he may be, Macheath appears sincere. However, even this repentant man, this victim, is dismissed in the song's second stanza when he lashes out at other sinners - the crooks, "girls who flaunt their treasure," "cat-house owners," "dogs in uniforms"-as if he were seeking absolution by arguing that all people are sinners, and so he is not unique, and hence any judgment is irrelevant.

I was reminded here of Shakespeare's King Lear's horrendous indictment: "the strong lance of justice hurtles breaks. Arm it in rags, a pigmy's straw does pierce it," which leads to his "None does offend, none, I say, none, I'll able 'em" (4.5.156-58). All men and women are sinners, and so no one can cast blame on another. Since we are all lost, Lear will come to the aid of, will love all people regardless of the charges against them. Macheath, however, departs from Lear's morality or relativity, for he ends the song viciously and vengefully, insisting he is "guiltless" but then praying "heavy hatchets hit [his 
accusers'] faces, "smashing them in for all to see," boasting that he now "forget[s] their filthy faces" even as he begs the very people he has just condemned to "pardon" him. The song is illogical, replete with the wild charges one would expect from the most desperate. It offers a brief mirror for the roiling, complex, contradictory heart of Macheath, even as it exposes him at his most savage. Ours was definitely a different Macheath from Jesse Martin's, dismissed by one reviewer as lacking "danger or grandeur," as little more than a "small-time" thief, ${ }^{26}$ or the Macheath at the New Jersey Shakespeare Festival who tracked his crimes on a laptop. ${ }^{27}$

Despite that harsh music, staccato beat, and absence of a clear melody, we tried to make Macheath's three songs appeal to and involve the audience precisely because they were so different from the rest of the score. They formed a dramatic monologue, the music functioning somewhat like that of the recitative in opera.

\section{The Larger World}

To a degree that the conventional musical often does not, or cannot, The Threepenny Opera opens to a world outside the theatre, so much so that at times it has the feeling of a documentary. In the American Conservatory Theatre production the actors adopted a "histrionic, silent-film style," underscoring the piece as "a political fable." 28 Like his epic theatre itself, the Brechtian actor is no slave to illusion. Macheath recognizes this larger public, political obligation in his speech just before the arrival of the Messenger (59). He defends the "little handicraft workers and safecrackers, plying industriously [their] jimmies and billy-hacks upon the safes and cash boxes of little business men." For him, criminality is a slippery, relative term. Whatever his responsibility in the impending execution, it is also a "pyramiding combination of unfortunate circumstances" that remains the major cause. Relatively small harm is done to society by "the robbing of a bank" compared to the exploitation resulting from founding a bank that ultimately supports a privileged class, or forecloses on the mortgages of little people. We also restored the alternate line in the Blitzstein text: "What is the killing of a man, compared to the subjection of a man?"

The Threepenny Opera may treat such Marxist analysis of society only intermittently, unlike the full-scale analysis of, say, The Caucasian Chalk Circle or Galileo, but it is there nevertheless. One complaint often heard about some

26. Brantley, "The Fine Art of Slumming It."

27. Alvin Klein, "Man's Sorry Lot, as Depressingly True as Ever," New York Times, last modified July 20, 1997, accessed August 6, 2011, goo.gl/B74UXu.

28. David Patrick Stern, "Reworked Threepenny Cashes in on Sex, Politics," USA Today, last modified September 14, 1999, accessed August 6, 2011, goo.gl/Sey04H. 
current productions is that they lack the "snarl and bite [of] social commentary," or that for the audience "the jibes at hypocrites, cons, and society have become part of conventional wisdom."29

Nowhere is this seriousness more insistent than when, moments after Macheath' s speech, the Messenger arrives, and the work admits a happy ending that only calls such endings into doubt. Our The Threepenny Opera ended with the full cast, a spectrum of society, our small stage ${ }^{30}$ crowded with types. The show had opened with the same spectrum, the parade of shopkeepers, whores, con artists, regular citizens, low- and middle-class characters providing a visual accompaniment to the overture, that raucous, knife-like cabaret music where Weill clearly reminds us of the uncertain and dangerous final days of the Weimar Republic when a decadence, an indifference to the future had spread over Berlin, in part the product of a regime foreign to the history and culture of the German people. Here that uncertainty is captured by this most challenging musical, one that senses the coming of National Socialism that would prove the country's fatal liberator. ${ }^{31}$

\section{Conclusion}

Almost fifty years earlier I had asked Miss Lenya and her fellow actors, "What was it like staging the show in Nazi Germany? Doing Threepenny now, in America?" Now I had the opportunity to incorporate their answers into my production.

Conventional musical comedy has a central place in the theatre, as "entertainment" in its best sense of that word. The Threepenny Opera abides by conventions of the genre, that basic trinity of story, song, and dance, enriching even as it often parodies and thereby questions it. But this work by Brecht and Weill also reflects on and anticipates more unconventional musical comedies, with its complex characters, the productive violation of a liner plot, the integration of music and story to the degree that they are inseparable-and sometimes even indistinguishable, its balance between the aesthetics of seemingly hermetically-sealed world onstage and its mirror to the real world beyond the immediate theatre, and to the ways its engages the audience,

29. Winn, "Bright, Polished "Threepenny"."

30. John Willett, "Ups and downs of British Brecht," in Re-interpreting Brecht: His Influence on Contemporary Drama and Film, ed. Pia Kleber and Colin Visser (New York: Cambridge University Press, 1990), 87.

31. In their introduction to Brecht on Art and Politics, Tom Kuhn and Steve Giles observe that with The Threepenny Opera Brecht abandoned "the anarchistic nihilism of his early plays in favor of behaviorist materialism in the mid-1920s," (Tom Kuhn, and Steve Giles, ed., Brecht on Art and Politics (London: Bloomsbury Publishing PLC, 2003), 57). 
asking for more than just their attention. The Threepenny Opera was and remains the benchmark for the joys and challenges of the unconventional musical comedy.

\section{Bibliography}

Allfree, Clare. "The Threepenny Opera, National Theatre, review: 'It chills more than it thrills'." The Telegraph. Last modified May 27, 2016. Accessed February 10, 2017. goo.gl/G75DGm.

Binelli, Mark. "Hamilton Creator Lin-Manuel Miranda: The Rolling Stone Interview." Rolling Stone Magazine, June 1 (2016). Accessed January 12, 2017. goo.gl/PfsOui.

Bordman, Gerald. American Musical Theatre: A Chronicle. New York: Oxford University Press, 1978.

Brantley, Ben. "The Fine Art of Slumming It." The New York Times. Last modified July 4, 2003. Accessed August 6, 2011. goo.gl/j9PZrG.

Brecht, Bertolt. The Threepenny Opera - English book by Desmond Vesey, English lyrics by Eric Bentley, A foreword by Lotte Lenya, edited by Eric Bentley. New York: Grove Press, 1964.

Crisafulli, Chuck. "Unconventional Musical Sing a Different Tune." Entertainment News. Last modified November, 16, 2007. Accessed January 12, 2017. goo.gl/FKSIY1.

Esslin, Martin. Bertolt Brecht - Issue 42. New York: Columbia University Press, 1969.

Ewen, David. The Story of American Musical Theater. Philadelphia: Chilton, 1961, [1st ed.].

Fuegi, John. Brecht and Company: Sex, Politics, and the Making of the Modern Drama. New York: Grove Press, 1994.

Genzlinger, Neil. "Those Beggars and Thieves Are on the Loose." The New York Times. Last modified September 10, 2003. goo.gl/h3dYXf.

Gilbert, Michael John T. Bertolt Brecht's Striving for Reason, Even in Music: A Critical Assessment. New York: Peter Lang, 1988.

Gray, Ronald. Brecht the Dramatist. Cambridge: Cambridge University Press, 1978

Hecht, Werner. "The Development of Brecht's Theory of Epic Theater: 19181933." Tulane Drama Review 6 (1961): 94-96.

Henderson, Steven. "The Persistence of Brecht." American Theatre 15, no. 5 (May/June, 1998): 12-19.

Homan, Sidney. Beckett's Theater's: Interpretations for Performance. Lewisburg, PA: Bucknell University Press, 1984. 
Klein, Alvin. "Man's Sorry Lot, as Depressingly True as Ever." New York Times. Last modified July 20, 1997. Accessed August 6, 2011. goo.gl/B74UXu.

Kuhn, Tom, and Giles, Steve, ed. Brecht on Art and Politics. London: Bloomsbury Publishing PLC, 2003.

Mairowitz, David Z. The Threepenny Opera by Bertold Brecht/Kurt Weill - Plays and Players. Accessed August 6, 2011. goo.gl/eQRbvS.

Mead, Rebecca. "All about Hamilton." The New Yorker. February 9, 2015. Accessed January 12, 2017. goo.gl/pdStfT.

Murray, Matthew. "Off Broadway Reviews - 6 Women With Brain Death." Talkin' Broadway. Accessed August 6, 2011. goo.gl/xbA1qE.

Needle, Jan R., and Thompson, Peter. Brecht. Chicago: University of Chicago Press, 1981.

Perlmutter, Sharon. "Regional Reviews: Los Angeles - The Threepenny Opera." Talkin' Broadway. Accessed December 15, 2017. goo.gl/n18ZBb.

Rooney, David. "Review: Broadway: The American Musical." Variety. Last modified October 19, 2004. Accessed February 10, 2017. goo.gl/zK8Csb.

Siegel, Ed. "Threepenny Production Is on the Money." The Boston Globe. Last modified January 13, 2004. Accessed August 6, 2011. goo.gl/BVjuoW.

Sokel, Walter H. "Brecht's Concept of Character." Comparative Drama 3 (1971): 177-192.

Steer, W. A. J. "Brecht's Epic Theatre: Theory and Practice." Modern Language Review 63 (1968).

Stempel, Larry. Showtime: A History of the Broadway Musical Theater. New York: W.W. Norton, 2010.

Stern, David Patrick. "Reworked Threepenny Cashes in on Sex, Politics." USA Today. Last modified September 14, 1999. Accessed August 6, 2011. goo.gl/Sey04H.

The Most Influential Broadway Shows of All Time. Accessed January 12, 2017. goo.gl/q5Eqju.

Willett, John. The Theater of Bertolt Brecht. New York: New Directions, 1968.

Willett, John. "Ups and downs of British Brecht." In Re-interpreting Brecht: His Influence on Contemporary Drama and Film, edited by Pia Kleber and Colin Visser. New York: Cambridge University Press, 1990.

Wilmeth, Don B., and Miller, Tice L. ed. Cambridge Guide to American Theatre. Cambridge: Cambridge University Press, 1996, [2nd ed.].

Winn, Steven. "Bright, Polished "Threepenny"/"Opera's" four principal women turn in brilliant performances at ACT." San Francisco Gate. Last modified September 10, 1999. Accessed August 6, 2011. goo.gl/mfrf2j. 
